Gut, 1986, 27, 1298-1305

\title{
Establishment of an animal model of ovalbumin sensitised mouse to study protein induced enteropathy
}

\author{
C MALO AND C L MORIN \\ From the Centre de Recherche Pédiatrique, Service de Gastroentérologie, Hôpital Sainte-Justine Université de \\ Montréal, Montréal, Québec, Canada
}

SUMmARY The protein induced modifications of the small bowel mucosa from ovalbuminsensitised mouse have been studied in organ culture. A decrease in $\gamma$-glutamyl transpeptidase, alkaline phosphatase, lactase, sucrase, and glucoamylase activities was observed in the explants cultured in the presence of ovalbumin. In contrast, a large increase of those enzymatic activities was noted in the culture media, the overall effect observed being a net stimulation of the total enzymatic activities of the culture system. The enzymes accumulated in the particulate fraction of the medium (brush border membrane fraction) suggesting an increased turnover of membrane components by a process of shedding or microvesiculation. This model serves as a useful tool in evaluating the local response of the small bowel mucosa induced by a specific protein.

The intestinal mucosa represents a barrier which prevents the penetration of intraluminal substances such as micro-organisms, toxins and food antigens. An efficient immune defence mechanism has been developed in order to combat the assault of potentially harmful antigens present in the intestinal lumen. During early infancy, the functional immaturity of the immunological defence explains the relatively high incidence of intestinal protein intolerance such as cow's milk protein induced enteropathy. ${ }^{2}$ In fact, an absence of local antibodies in the intestinal mucosa is associated with an increased intestinal permeability to macromolecules leading to an increased incidence of circulating antibodies. ${ }^{3}$ Both systemic anaphylaxis reactions and local intestinal manifestations are observed in cow's milk protein induced enteropathy in children. ${ }^{4}$

These two types of reaction have been used to support the diagnosis of cow's milk protein induced enteropathy by means of clinical, immunological, biochemical, and morphological criteria. The elimination challenge test according to the clinical criteria described by Goldman et al $l^{5}$ deal with both local and systemic manifestations while the immunological approaches proposed $^{6-11}$ are mainly con-

Address for correspondence: Christiane Malo, PhD. Département de physiologie. Faculté de médecine. Université de Montréal, C.P. $6208-$ Succursale A. Montréal, Québec. Canada H3C 3T8.

Received for publication 28 February 1986. cerned with circulating antibodies. Local intestinal responses have also been evaluated by means of the one hour blood xylose test, ${ }^{12}$ changes in disaccharidases activities ${ }^{12} 13$ and histological modifications..$^{1314}$ These approaches are, however, whether potentially dangerous, not sufficiently reliable or non-specific for a peculiar enteropathy. Thus, the study of protein intolerance in man remains a complex problem as there is (1) a great similarity of symptoms in a variety of enteropathies; (2) no reliable laboratory test; (3) both local and systemic manifestations; and (4) important variations in the level of sensitivity from one person to another.

In this regard, experimental animal models for the study of allergic enteropathy represent an excellent tool to evaluate the response of the organism in contact with a specific allergen. Successful induction of sensitisation in an animal requires strict attention to the type and dose of the antigen, the strain and age of the animal, the route of immunisation and the requirement of an adjuvant. ${ }^{15}$ Furthermore, we must be conscious that active sensitisation induces both systemic and intestinal anaphylaxis responses ${ }^{16-19}$ which are difficult to dissociated by in vivo experiments.

In the present study, we show the usefulness of the organ culture technique to study in vitro the local response of the intestinal mucosa in contact 
with a specific allergen. This approach allows the study of the direct effects of an antigen on the intestinal tissue without any interference of systemic anaphylaxis manifestations.

\section{Methods}

ANIMALS

Male Swiss ICR mice, 3 weeks old, were used for all experiments. They were maintained on standard mouse laboratory diet until the end of the experimental period.

\section{IMMUNISATION PROCEDURE}

Lyophylised ovalbumin (Sigma Chem Co, St-Louis, Mo.) was used as immunogen and $\mathrm{AlPO}_{4}$ as immunological adjuvant. All animals were injected subcutaneously on the dorsal surface with the mixture: ovalbumin $(1 \mu \mathrm{g}) \mathrm{AlPO}_{4}(1.5 \mathrm{mg})$ in $0.2 \mathrm{ml}$ volume. Two weeks later, the same injection was repeated as a booster. Fifteen days later, ovalbumin was given in the drinking water $(1 \mathrm{mg} / \mathrm{ml})$ for a nine day period.

PASSIVE CUTANEOUS ANAPHYLAXIS REACTION The presence of reaginic antibodies against ovalbumin was evaluated according to the procedure of Levine et al. ${ }^{20}$ Briefly, $0.03 \mathrm{ml}$ of a $1 / 10$ serum dilution was injected intradermally at three different sites on the shaven dorsal surface of CFW strain recipient mice. Forty eight hours later, passive cutaneous anaphylaxis reaction (PCA) was induced by intravenous (iv) injection of $100 \mu \mathrm{g}$ ovalbumin in $0.2 \mathrm{ml}$ Evan's blue (0.5\%) in the tail vein. A positive reaction was established as a dark blue circle of at least $5 \mathrm{~mm}$ diameter, 30 minutes after the iv injection. Three mice were used for each serum tested.

\section{CULTURE CONDITIONS}

At the end of the immunisation procedure, animals were fasted overnight. Blood was collected by cardiac puncture and serum was separated for both PCA reaction and preparation of the culture media. Animals were then killed by cervical dislocation. A $4 \mathrm{~cm}$ segment of the small intestine, taken $11 \mathrm{~cm}$ distal to the pylorus, was rapidly removed, rinsed in culture medium and cut into 45 explants $(2 \times 3 \mathrm{~mm})$ as previously described. ${ }^{21}$ The culture media and the conditions used were those established by Ferland $e t$ $a l^{22}$ for adult mouse small intestinal organ culture. At the end of the culture period, 42 explants were pooled for biochemical determinations and three explants were fixed for light microscopy.

IN VITRO CHALLENGE

A three hour period was allowed for the adaptation of the explants to the culture conditions. After this time, media were renewed. The experimental groups received the following mixture: DMEMHepes/NCTC 135/sensitised mouse serum in the proportion 9:1:1, supplemented with $40 \mu \mathrm{g}$ gentamycine and either $0.2,1.0$ or $5.0 \mathrm{mg}$ ovalbumin $/ \mathrm{ml}$ of medium. The controls were cultured under the same conditions either without added protein in the medium or with $\beta$-lactoglobulin (Sigma Chem Co, St-Louis, Mo.) at the same concentrations used for ovalbumin. The Falcon dishes were then maintained at $37^{\circ} \mathrm{C}$ in $95 \% \mathrm{O}_{2} / 5 \%$ $\mathrm{CO}_{2}$ atmosphere for 24 hours. Media were purchased from GIBCO (Grand Island Biological Co. of Canada, Burlington, Ont.).

${ }^{3}$ H-THYMIDINE INCORPORATION INTO DNA

The last three hours of culture served to determine ${ }^{3} \mathrm{H}$-thymidine incorporation into DNA in the presence of $2 \mu \mathrm{Ci}$ of radioactive thymidine (Spec act: 79.6 Ci/mmol, New England Nuclear Canada, Lachine, Québec) per ml medium.

At the end of the culture period, 42 explants were pooled, dried on a millipore filter paper and weighed before homogenisation in cold redistilled water. An aliquot of $0.5 \mathrm{ml}$ of homogenate was used to analyse radioactive precursors incorporation into DNA as previously described ${ }^{21}$ and the remaining volume was used for biochemical determinations.

\section{BIOCHEMICAL DETERMINATIONS}

Enzymatic activities were determined in the tissues as well as in the culture media. Sucrase and lactase activities were assayed according to a modification by Lloyd and Whelan ${ }^{23}$ of the Dalhlqvist's method. ${ }^{24}$ Glucoamylase was assayed with soluble starch as substrate according to Schlegel-Haueter $e t$ $a l,{ }^{25} \gamma$-glutamyl transpeptidase $(\gamma-\mathrm{GT})$ according to Naftalin $e t a l^{26}$ and alkaline phosphatase (AlPase) according to Eichholz. ${ }^{27}$ Tissue proteins were evaluated by the technique of Lowry et $a l^{28}$ by using crystalline bovine serum albumin as standard. DNA Contents were determined according to the modification by Giles and Myers ${ }^{29}$ of the Burton's method, ${ }^{30}$ with calf thymus DNA as standard. Results were expressed as $\mu \mathrm{mol}$ of substrate hydrolysed per minute per gram of proteins.

\section{PROCESSING OF THE CULTURE MEDIA}

Culture media were centrifuged at $100000 \mathrm{~g}$ for 60 minutes. The supernatant $F_{s}$ (soluble fraction of the media) and the pellet $F_{p}$ (particulate fraction of the media), resuspended in $0.6 \mathrm{ml}$ cold redistilled water, were both assayed for enzymatic activities. In another set of experiments, brush border membranes were purified by the method of Schmitz et 
al. ${ }^{31} \mathrm{CaCl}_{2}$ addition was made by adding $0.5 \mathrm{ml}$ of a $50 \mathrm{mM}$ solution to the culture medium to give a final concentration of $10 \mathrm{mM}$. The pellet obtained after the first centrifugation $\left(\mathrm{P}_{1}\right)$ and the brush border membrane fraction $\left(\mathrm{P}_{2}\right)$ were both resuspended in $0.6 \mathrm{ml}$ cold redistilled water and used for biochemical determinations. The last clear supernatant $\left(\mathrm{S}_{2}\right)$ was then centrifuged at $100000 \mathrm{~g}$ for 60 minutes to yield a final pellet called $\mathrm{P}_{3}$.

\section{MICROSCOPIC STUDIES}

At the beginning of the experiment and at the end of the culture period, three explants were fixed in Bouin's fluid and embedded in Tissue-Prep. The 5 $\mu \mathrm{m}$ sections were stained with HPS or PAS technique.

\section{STATISTICAL ANALYSIS}

Results are expressed as the mean \pm SEM. Data were compared by the Student's $t$ test for paired data or by a one way analysis of variance and Bonferroni confidence intervals.

\section{Results}

\section{IMMUNISATION}

Primary immunisation with ovalbumin, followed by a booster injection two weeks later and a nine day period of oral administration of ovalbumin gave a positive PCA reaction in 92 mice over 97, with at least a $1 / 10$ serum dilution. This represents $95 \%$ of the animals tested.

DOSE RESPONSE STUDY

Three different concentrations of protein were tested for the in vitro challenge $(0.2,1.0$ and 5.0 $\mathrm{mg} / \mathrm{ml}$ medium). Nevertheless, only the highest dose gave constant response in each culture done. The data presented are therefore the results of a set of experiments using $5 \mathrm{mg}$ ovalbumin or $\beta$-lactoglobulin $/ \mathrm{ml}$ of medium.

\section{DETERMINATION OF CONTROL VALUES}

In a preliminary set of experiments, intestinal explants from both non-immunised and immunised mice were cultured for 24 hours without any added protein or with $\beta$-lactoglobulin or ovalbumin added into the culture medium. As shown in Table 1, protein and DNA contents were not significantly different between the four groups at the end of the culture period. Furthermore, enzymatic activities measured in the tissues as well as in the culture medium were not significantly altered by the presence of either ovalbumin or $\beta$-lactoglobulin (Table $2)$. In subsequent cultures, intestinal explants from immunised mice, cultured in the presence of $\beta$ lactoglobulin were used as controls. This procedure was adopted as it allows the comparison between identical pools of explants prepared from three different animals as shown in Table 3.

\section{${ }^{3}$ H-THYMIDINE INCORPORATION INTO DNA}

${ }^{3} \mathrm{H}$-thymidine incorporation into DNA was evaluated over a three hour period after the challenge. The results show a significant $24.6 \%$ decrease of ${ }^{3} \mathrm{H}$-thymidine incorporation into DNA in the ovalbumin-challenged cultures as compared with $\beta$-lactoglobulin-treated explants (Table 1). The DNA content of the tissues remains unchanged as well as the DNA recovered into the total medium (36.5 $\pm 3.8 \mu \mathrm{g}$ in $\beta$-lactoglobulin supplemented medium $v s 38.6 \pm 4.4 \mu \mathrm{g}$ in ovalbumin treated medium).

Table 1 Protein and DNA contents of intestinal explants and ${ }^{3} H$-thymidine incorporation into DNA

\begin{tabular}{|c|c|c|c|c|}
\hline & \multirow{2}{*}{$\begin{array}{l}\begin{array}{l}\text { Non-immunised } \\
\text { animals }\end{array} \\
+ \text { Ovalbumin }\end{array}$} & \multicolumn{3}{|c|}{ Immunised animals } \\
\hline & & Without protein & $+\beta$-lactoglobulin & +Ovalbumin \\
\hline Cultures (n) & $7 \dagger$ & 7 & 7 & 14 \\
\hline Protein content (mg/g tissue) & $82 \cdot 7 \pm 8 \cdot 0 \ddagger$ & $84 \cdot 2 \pm 4 \cdot 0$ & $89 \cdot 5 \pm 4 \cdot 2$ & $82 \cdot 5 \pm 9 \cdot 0$ \\
\hline DNA content ( $\mathrm{mg} / \mathrm{g}$ tissue) & $5 \cdot 8 \pm 0 \cdot 7$ & $5 \cdot 5 \pm 0 \cdot 3$ & $5 \cdot 4 \pm 0 \cdot 4$ & $5 \cdot 7 \pm 0 \cdot 3$ \\
\hline${ }^{3} \mathrm{H}$-thymidine incorporation (DPM/g DNA) & $146 \cdot 8 \pm 7 \cdot 3 \S$ & $159 \cdot 3 \pm 18 \cdot 8$ & $150 \cdot 8 \pm 5 \cdot 6$ & $115 \cdot 5 \pm 13 \cdot 3 \|$ \\
\hline
\end{tabular}

${ }^{*}$ Intestinal explants from non-immunised and immunised animals were cultured without added protein or with $5 \mathrm{mg} \beta$-lactoglobulin or ovalbumin per $\mathrm{ml}$ of medium.

†Each individual culture represents 45 intestinal explants taken equally from three different animals. From these 45 explants, three were fixed for light microscopy and 42 were pooled for biochemical determinations.

¥Mean \pm SFM

$\$^{3} \mathrm{H}$-thymidine incorporation into DNA was determined during the last three hours of culture with $2 \mu \mathrm{Ci}^{3} \mathrm{H}$-thymidine (Spec act: $79 \cdot 6$ $\mathrm{Ci} / \mathrm{mmol}$ ) per ml medium.

$\|$ Values significantly different $(\mathrm{p}<0.0005)$ from both non-immunised animals cultured with ovalbumin and immunised animals cultured without protein or in the presence of either $\beta$-lactoglobulin or ovalbumin in the culture medium. 
Table 2 Distribution of enzyme activities in cultures from immunised and non-immunised animals

\begin{tabular}{|c|c|c|c|c|}
\hline & & Tissue & Medium & Tissue + Medium \\
\hline AlPase* & $\begin{array}{l}\text { I } \dagger+\text { None } \\
\text { I+ } \beta \text {-lact. } \S \\
\text { NI } \|+ \text { OVA } \|\end{array}$ & $\begin{array}{l}103 \cdot 1 \pm 24 \cdot 9 \ddagger \\
148 \cdot 0 \pm 15 \cdot 0 \\
114 \cdot 4 \pm 13 \cdot 6\end{array}$ & $\begin{array}{l}588 \cdot 4 \pm 63 \cdot 2 \\
532 \cdot 7 \pm 66 \cdot 4 \\
536 \cdot 6 \pm 8 \cdot 4\end{array}$ & $\begin{array}{l}690 \cdot 5 \pm 69 \cdot 2 \\
680 \cdot 7 \pm 69 \cdot 8 \\
651 \cdot 0 \pm 5 \cdot 7\end{array}$ \\
\hline Sucrase & $\begin{array}{l}\text { I+None } \\
\text { I+ } \beta \text {-lact. } \\
\text { NI+OVA }\end{array}$ & $\begin{array}{l}23 \cdot 7 \pm 4 \cdot 1 \\
23 \cdot 6 \pm 4 \cdot 9 \\
25 \cdot 3 \pm 3 \cdot 8\end{array}$ & $\begin{array}{l}55 \cdot 6 \pm 5 \cdot 3 \\
54 \cdot 2 \pm 6 \cdot 9 \\
58 \cdot 4 \pm 6 \cdot 0\end{array}$ & $\begin{array}{l}79 \cdot 2 \pm 6 \cdot 0 \\
77 \cdot 9 \pm 9 \cdot 2 \\
83 \cdot 6 \pm 7 \cdot 0\end{array}$ \\
\hline Lactase & $\begin{array}{l}\text { I+None } \\
\text { I+ } \beta \text {-lact. } \\
\text { NI+OVA }\end{array}$ & $\begin{array}{l}3 \cdot 3 \pm 0 \cdot 6 \\
3 \cdot 3 \pm 0 \cdot 6 \\
3 \cdot 9 \pm 0 \cdot 1\end{array}$ & $\begin{array}{r}9 \cdot 5 \pm 1 \cdot 3 \\
12 \cdot 6 \pm 1 \cdot 3 \\
9 \cdot 6 \pm 1 \cdot 2\end{array}$ & $\begin{array}{l}12 \cdot 7 \pm 1 \cdot 5 \\
15 \cdot 8 \pm 1 \cdot 4 \\
13 \cdot 5 \pm 1 \cdot 2\end{array}$ \\
\hline $\mathrm{GA}^{* *}$ & $\begin{array}{l}\text { I+None } \\
\text { I+ } \beta \text {-lact. } \\
\text { NI+OVA }\end{array}$ & $\begin{array}{l}33 \cdot 3 \pm 3 \cdot 5 \\
41 \cdot 7 \pm 5 \cdot 6 \\
48 \cdot 2 \pm 11 \cdot 1\end{array}$ & $\begin{array}{l}220 \cdot 8 \pm 43 \\
224 \cdot 3 \pm 21 \cdot 6 \\
211 \cdot 2 \pm 6 \cdot 4\end{array}$ & $\begin{array}{l}254 \cdot 1 \pm 41 \\
226 \cdot 0 \pm 22 \cdot 4 \\
259 \cdot 3 \pm 7 \cdot 9\end{array}$ \\
\hline$\gamma \mathrm{GT}+\dagger$ & $\begin{array}{l}\text { I+ None } \\
\text { I+ } \beta \text {-lact. } \\
\text { NI+OVA }\end{array}$ & $\begin{array}{l}16 \cdot 8 \pm 1 \cdot 8 \\
17 \cdot 2 \pm 3 \cdot 2 \\
17 \cdot 7 \pm 1 \cdot 8\end{array}$ & $\begin{array}{l}57 \cdot 0 \pm 5 \cdot 2 \\
44 \cdot 2 \pm 9 \cdot 2 \\
57 \cdot 4 \pm 8 \cdot 9\end{array}$ & $\begin{array}{l}73 \cdot 6 \pm 5 \cdot 5 \\
60 \cdot 6 \pm 11 \cdot 5 \\
75 \cdot 2 \pm 8 \cdot 4\end{array}$ \\
\hline
\end{tabular}

*Alkaline phosphatase.

$\dagger \mathbf{I}=$ immunised animals.

$\ddagger$ Specific activities: $\mu \mathrm{mol}$ substrate hydrolysed/min/gram protein \pm SEM.

$\S \beta$-lactoglobulin $(5 \mathrm{mg} / \mathrm{ml}$ of medium).

$\| \mathrm{NI}=$ non-immunised animals.

ๆOvalbumin $(5 \mathrm{mg} / \mathrm{ml}$ of medium).

${ }^{* *}$ Glucoamylase.

$\dagger \dagger \gamma$-glutamyltranspeptidase.

Table 3 Distribution of explants from immunised animals cultured in different conditions

\begin{tabular}{llll}
\hline Animal & Explants $(n)$ & & \\
\hline 1 & 15 & 15 & 15 \\
2 & 15 & 15 & 15 \\
3 & 15 & 15 & 15 \\
& Culture & Culture & Culture \\
& + & + & + \\
& $\beta$-lactoglobulin & Ovalbumin & Ovalbumin \\
& & &
\end{tabular}

Each pool of 45 explants represents one culture on which one set of biochemical determinations was done. Duplicates of ovalbumin supplemented culture are compared with $\beta$-lactoglobulin treated tissues taken as control.

\section{ENZYMATIC ACTIVITIES}

Results of various enzyme determinations from cultures in the presence of $\beta$-lactoglobulin or ovalbumin are shown in Figure 1. The activity of $\gamma-\mathrm{GT}$ is significantly depressed in the tissue when compared with control values. Nevertheless, a large increase is observed in the culture medium, leading to a net stimulation of the total enzymatic activity (tissue +medium). The same type of response is observed for AlPase activity as well as for lactase, sucrase, and glucoamylase. The percentage of total increase over the control values is always highly significant, even if the stimultion is less important in the case of sucrase and glucoamylase.
PARTICULATE FRACTIONS OF THE MEDIA In order to evaluate the form of these enzymatic activities in the medium, different sedimentable fractions were prepared. After one hour centrifugation of the media at $100000 \mathrm{~g}, 85$ to $100 \%$ of the enzymatic activities were recovered in the particulate fraction $\left(F_{p}\right)$ of the media, except for glucoamylase which appeared more soluble (Fig. 2). When brush border membrane fractions were purified, the enzymatic activities were found mainly associated with the $\mathrm{P}_{2}$ fraction (bbm). A large proportion of the sedimentable enzymatic activities, however, was recovered in the last pellet $P_{3}$.

\section{MORPHOLOGY OF THE EXPLANTS}

A good preservation of the histological appearance of the explants was recorded from explants cultured without any added protein or in the presence of $\beta$-lactoglobulin or ovalbumin in the medium, when compared with tissues taken up at the beginning of the culture. Furthermore, no noticeable difference in villous architecture, crypt regions, lymphocyte infiltration into the lamina propria or oedema was noted between control or experimental intestinal explants.

\section{Discussion}

Sensitised animals have been widely used to study the local response of the intestinal mucosa in contact 


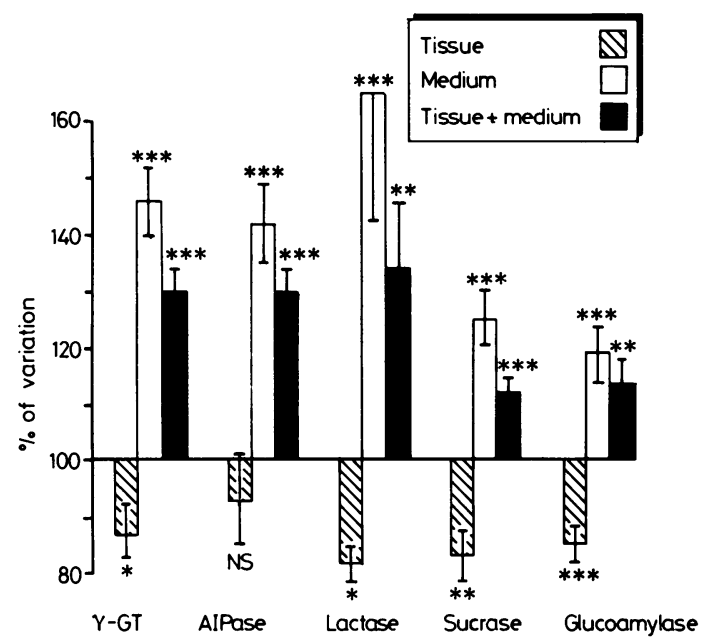

Fig. $1 \quad \gamma$-glutamyl transpeptidase $(\gamma-G T)$, alkaline phosphatase (AlPase), lactase, sucrase and glucoamylase activities in the tissues, in the culture medium and total activity (tissue +medium) after 24 hours of culture in the presence of $5 \mathrm{mg}$ ovalbumin $/ \mathrm{ml}$ medium. The values of control tissues cultured in the presence of $\beta$-lactoglobulin at the same concentration, are set as $100 \%$ activity. Results are calculated in $\mu \mathrm{mol}$ substrate hydrolysed/min and/g protein or mg tissue wet weight and represented as percentage of control's value ${ }^{*}=p<0 \cdot 01$, $* *=p<0.0025, * * *=p<0.0005$. with a specific allergen. Anaphylactic release of intestinal goblet cell mucus, ${ }^{18}$ migration inhibition of lymph node lymphocytes, ${ }^{32}{ }^{33}$ decrease in $\mathrm{H}_{2} \mathrm{O}$, $\mathrm{Na}, \mathrm{K}$, and $\mathrm{Cl}$ absorption, ${ }^{34}$ increase in antigen absorption ${ }^{19}$ and stimulation of secretory IgA production in the small intestine ${ }^{35}$ have been reported after local application of the antigen to the intestinal mucosa.

The establishment of an animal model sensitised to a food protein could prove useful in the research of food allergy and could lead to an in vitro test for the diagnosis of food protein intolerance in clinical medicine. Because small intestinal organ culture technique of Swiss ICR mice has already been developed, ${ }^{21} 22$ we have adapted the immunisation procedures already applied to rats ${ }^{36}$ and mice ${ }^{20}$ to our strain of mice and our conditions. The dose of allergen and adjuvant, the delay of immunoglobulins production after the primary sensitisation, the effect of a booster and the route of administration have been studied. Our procedure gives very good results since $95 \%$ of the animals tested produce a positive response.

The second step of this study was the evaluation, in vitro, of the response of the small bowel mucosa in contact with ovalbumin. This approach allowed the possibility of studying the local response of the intestinal mucosa in contact with a specific protein. Attention had to be paid to the preparation of the

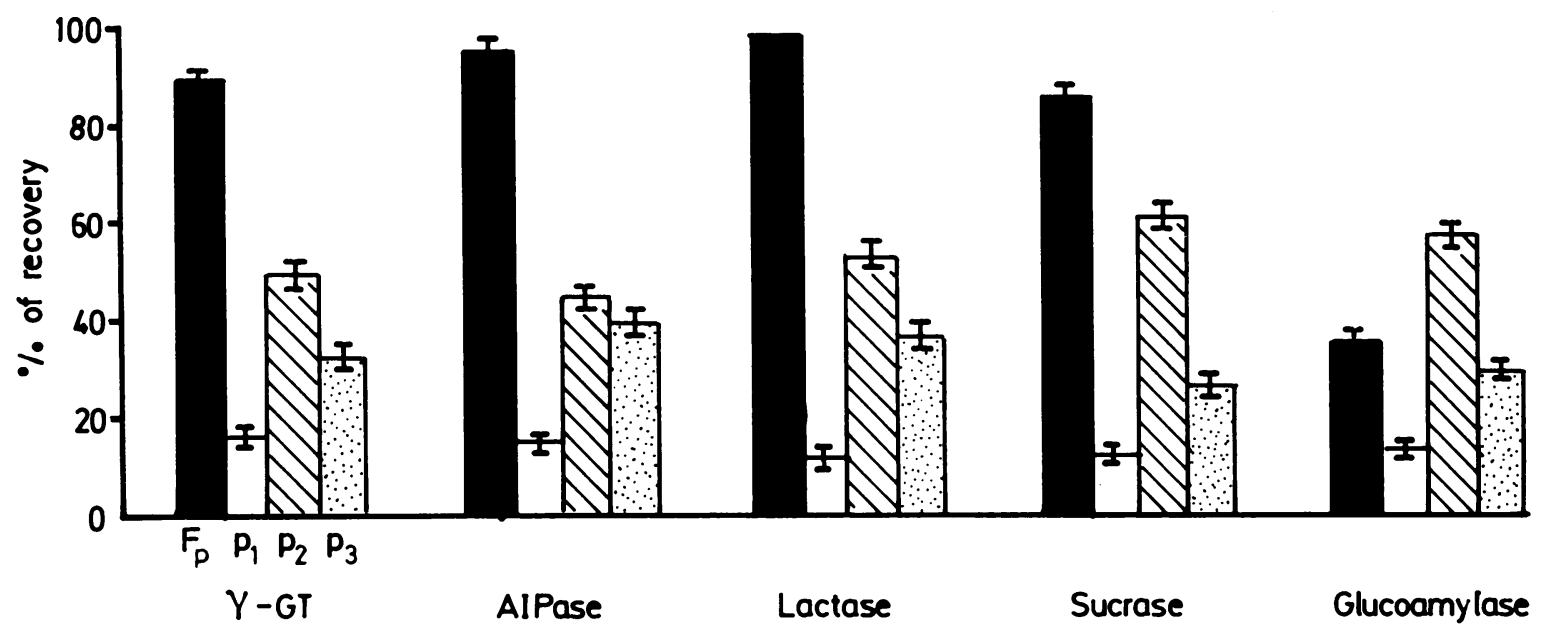

Fig. 2 Percentage of recovery of alkaline phosphatase (AlPase), $\gamma$-glutamyl transpeptidase $(\gamma$-GT) lactase, sucrase and glucoamylase activities in the particulate fraction $\left(F_{p}\right)$ of the culture media obtained by ultracentrifugation at $100000 \mathrm{~g}$ for $60 \mathrm{~min}$. In another set of experiments, brush border membranes $(\mathrm{bbm})$ were purified in presence of $\mathrm{CaCl}_{2}$. The bbm were recovered in the $P_{2}$ fraction. A final step of ultracentrifugation at $100000 \mathrm{~g}$ gave a last pellet called $P_{3}$. The results were expressed as percentage of recovery with respect to the total enzymatic activities in the culture medium. 
tissues, however, the means of expressing the results, and the choice of the controls. Tissues from immunised animals cultured in presence of $\beta$ lactoglobulin represent adequate controls as we have shown that there is no difference in protein and DNA contents as well as in ${ }^{3} \mathrm{H}$-thymidine incorporation and enzymatic activities between these and explants from non-immunised animals. Furthermore, our procedure eliminated the variability from mouse to mouse in the same experiment, and from one culture to another as equivalent tissues are simultaneously compared under different experimental conditions. Preliminary experiments have underlined the necessity of using mouse sensitised serum instead of fetal calf serum to obtain a specific response (data not shown). This point has also been documented during an in vitro challenge of the bone marrow to study drug induced pancytopenia. ${ }^{37}$ Furthermore, an increased production of lymphocyte-migration-inhibition factor by peripheral blood lymphocytes has recently been demonstrated in vitro in patients suffering from cow's milk protein induced enteropathy. ${ }^{10}$

The choice of ovalbumin concentration in the culture medium was based on methodology used for in vitro experiments on gluten sensitive enteropathy. ${ }^{38-40}$ Only the highest dose of $5 \mathrm{mg}$ ovalbumin/ml medium gave constant responses in each experiment. One can argue that this concentration of protein is unphysiologically high. In vivo experiments with local application of the allergen to the intestinal mucosa by intraduodenal gavage were conducted with much higher concentrations, however, ranging from $100-500 \mathrm{mg} \cdot{ }^{18}{ }^{19}$ Furthermore, the fact that both immunised and non-immunised controls cultured with or without the same amount of protein did not show any changes in biochemical parameters and no noticeable modification of the morphological appearance of the tissue after culture with the allergen argues against a non-specific response induced by cytotoxic effect of the protein or by a different nutritional value of the bathing media.

Our results show a net decrease of enzymatic activities in the tissue. This phenomenon was also observed in the study of Iyngkaran et al $l^{41}$ after 24 hours of culture of human small bowel biopsies from patients with cow's milk protein induced enteropathy in the presence of cow's milk. Only the activity of AlPase was reported in this study, however, and no determination was made on the culture medium. Our data clearly demonstrate a large increase of enzymatic activities in the culture medium leading to a net stimulation of the total activities of the culture system for all enzymes studied.
This raises questions about the mechanism involved in this accumulation of enzymatic activities. One explanation can be an increase of cell desquamation. This hypothesis is not supported by the fact that the quantity of DNA recovered in the medium is the same in the controls and ovalbuminchallenged cultures. Thus; there is no increased cell loss. Another explanation may be the accelerated renewal of some membrane components by a process of shedding or microvesiculation. In this case, enzymatic activities should be associated with membrane fragments and thus, could be recovered in a particulate fraction of the culture medium. Our results indicate that the enzymatic activities are associated with a bbm fraction, suggesting that this response may be a physiological process of membrane component renewal. Shedding or microvesiculation has already been observed in a variety of systems. These include organ culture of small intestine from adult ${ }^{42}$ and suckling mice, ${ }^{21}$ intestinal organ culture of chick embryo, ${ }^{4.3}$ adult intestine in situ, ${ }^{44}$ cell culture from normal and neoplastic origin $^{45}$ and urine and duodenal fluid from man. ${ }^{46}$ The exact physiological function of these vesicles, however, remains to be elucidated.

In conclusion, we believe that this in vitro animal model can be used to evaluate the response of the intestinal mucosa in contact with a specific protein. Because the organ culture technique for human small intestine is well established, ${ }^{+7}$ such a model could then eventually lead to an in vitro test for the diagnosis of intestinal protein induced enteropathy in patients, and more specifically in children with cow's milk protein induced enteropathy.

This study was supported by the Fondation Justine Lacoste - Beaubien and by the Medical Research Council of Canada (Grant MT 3320). C Malo was supported by a fellowship from the MRC of Canada. The authors gratefully acknowledge the technical assistance of Carole Garofalo-Ratelle. This work was presented in part at the annual meeting of the Society for Pediatric Research, Washington, DC, May 1985, and has been published in abstract form. ${ }^{1}$

\section{References}

1 Malo C, Morin CL. Establishment of an animal model of ovalbumin-sensitised mouse to study protein intolerance in vitro. [Abstract]. Pediatr Res 1985; 19: 696A.

2 Visakorpi JK. The immune response of the intestinal mucosa to foreign proteins. Acta Paediatr Scand 1982; 296: $56-9$.

3 Walker WA, Hong R. Immunology of the gastrointestinal tract. Part II. J Pediatrics 1973; 83: 711-20.

4 Dobbins WO. Gut immunophysiology: a gastroenter- 
ologist's view with emphasis on pathophysiology. Am J Physiol 1982; 242: G1-G8.

5 Goldman AS, Anderson DW, Sellers WA, Saperstein S, Kniker WT, Halpern SR. Milk allergy. 1. Oral challenge with milk and isolated milk proteins in allergic children. Pediatrics 1963; 32: 425-43.

6 Björksten B, Ahlstedt S, Björksten F, et al. Immunoglobulin E and immunoglobulin G4 antibodies to cow's milk in children with cow's milk allergy. Allergy 1983; 38: 119-24.

7 Shiner M, Ballard J, Smith ME. The small-intestinal mucosa in cow's milk allergy. Lancet $1975 ; 2$ : 136-40.

8 Kuitunen P, Visakorpi JK, Sarilahti E, Pelkonen P. Malabsorption syndrome with cow's milk intolerance: clinical findings and course in 54 cases. Arch Dis Child 1975; 50: 351-6.

9 Penner E, Katz LA, Milgrom F. Microsomal antibody and circulating immune complexes in allergic gastroenteropathy. Lancet 1978; 1: 669.

10 Ashkenazi A, Levin S, Idar D, Or A, Rosenberg I, Handzel ZT. In vitro cell-mediated immunologic assay for cow's milk allergy. Pediatrics 1980; 66: 399-402.

11 Scheinmann P, Gendrel D, Charles J, et al. Value of lymphoblast transformation test in cow's milk protein intestinal intolerance. Clin Allergy 1976; 6: 515-21.

12 Morin CL, Buts JP, Weber A, Roy CC, Brochu P. One-hour blood-xylose test in diagnosis of cow's milk protein intolerance. Lancet 1979; 1: 1102-4.

13 Iyngkaran N, Robinson MJ, Prathap K, Sumithran E, Yadav M. Cow's milk protein-sensitive enteropathy. Combined clinical and histological criteria for diagnosis. Arch Dis Child 1978; 53: 20-6.

14 Shiner M, Ballard J, Brook CGD, Herman S. Intestinal biopsy in the diagnosis of cow's milk protein intolerance without acute symptoms. Lancet 1975; 2: 1060-3.

15 Lake AM. Experimental models for the study of gastrointestinal food allergy. Ann Allergy 1983; 51: 226-8.

16 Pierce NF, Koster FT. Priming and suppression of the intestinal immune response to cholera toxin/toxoid in rats. J Immunol 1980; 124: 307-11.

17 Murray M, Jarrett WFH, Jennings FW. Mast cells and macromolecular leak in intestinal immunological reactions. The influence of sex of rats infected with Nippostrongylus brasiliensis. Immunology 1971; 21: 17-21.

18 Lake AM, Bloch KJ, Sinclair KJ, Walker WA. Anaphylactic release of intestinal goblet cell mucus. Immunology 1980; 39: 173-8.

19 Bloch KJ, Walker WA. Effect of locally induced intestinal anaphylaxis on the uptake of a bystander antigen. J Allergy Clin Immunol 1981; 67: 312-6.

20 Levine BB, Vax NM. Effect of combinations of inbred strain, antigen, and antigen dose on immune responsiveness and reagin production in the mouse. Int Arch Allergy 1970; 39: 156-71.

21 Malo C, Arsenault P, Ménard D. Organ culture of the small intestine of the suckling mouse in a serum-free medium. Cell Tissue Res 1983; 228: 75-84.

22 Ferland S, Hugon JS. Organ culture of adult mouse intestine. I. Morphological results after 24 and 48 hours of culture. In Vitro 1979; 15: 278-87.
23 Lloyd S, Whelan W. An improved method for enzymic determination of glucose in the presence of maltose. Anal Biochem 1969; 30: 467-70.

24 Dahlqvist A. Method for assay of intestinal disaccharidases. Anal Biochem 1964; 7: 18-25.

25 Schlegel-Haueter S, Hore P, Kerry KR, Semenza G. The preparation of lactase and glucoamylase of rat small intestine. Biochim Biophys Acta 1972; 258: 506-19.

26 Naftalin L, Sexton M, Whitaker JF, Tracey D. A routine procedure for estimating serum $\gamma$ glutamyltranspeptidase activity. Clin Chim Acta 1969; 26: 293-6.

27 Eichholz A. Structural and functional organisation of the brush border of intestinal epithelial cells. III. Enzymic activities and chemical composition of various fractions of tris-disrupted brush borders. Biochim Biophys Acta 1967; 135: 475-82.

28 Lowry OH, Rosebrough NF, Farr AL, Randall RJ. Protein measurement with folin phenol reagent. J Biol Chem 1951; 193: 265-75.

29 Giles KW, Myers A. An improved diphenylamine method for the estimation of deoxyribonucleic acid. Nature 1965; 4979: 93.

30 Burton K. A study of the conditions and mechanisms of the diphenylamine reaction for the colorimetric estimation of deoxyribonucleic acid. Biochem $J$ 1956; 62: 315-23.

31 Schmitz J, Preiser H, Maestracci D, Ghosh BK, Cerda JJ, Crane RK. Purification of the human intestinal brush border membrane. Biochim Biophys Acta 1973; 323: $98-112$.

32 Mowat AMcI, Ferguson A. Migration inhibition of lymph node lymphocytes as an in vitro assay for cell - mediated immunity in the draining lymph nodes of parenterally immunised mice. Immunology 1982; 47: 357-64.

33 Mowat AMcI, Ferguson A. Migration inhibition of lymph node lymphocytes as an assay for regional cell - mediated immunity in the intestinal lymphoid tissues of mice immunised orally with ovalbumin. Immunology 1982; 47: 365-70.

34 Grant Gall D, Chung M. Intestinal $\mathrm{H}_{2} \mathrm{O}$ and electrolyte transport during mucosal IgE mediated reactions. [Abstract]. Pediatr Res 1981; 16: 162A.

35 Pierce NF, Cray WC. Determinants of the localisation, magnitude and duration of a specific mucosal IgA plasma cell response in enterically immunised rats. J Immunol 1982; 128: 1311-5.

36 Bazin H, Platteau B. Production of circulating reaginic (IgE) antibodies by oral administration of ovalbumin to rats. Immunology 1976; 30: 679-84.

37 Kelton JG, Huang AT, Mold N, Logue G, Rosse WF. The use of in vitro technics to study drug-induced pancytopenia. $N$ Engl J Med 1979; 301: 621-4.

38 Olives JP, Schmitz J, Jos J, De Tand MF, Rey J. Cytotoxicité intestinale in vitro de diverses fractions de gliadine ou de protéines du lait de vache chez l'enfant: évaluation quantitative par une technique morphométique. Gastroenterol Clin Biol 1982; 16: 557-62.

39 Hauri HP, Kedinger M, Haffen K, Gaze H, Hadorn B, Hekkens W. Re-evaluation of the technique of organ 
culture for studying gluten toxicity in coeliac disease. Gut 1978; 19: 1090-8.

40 Mitchell JD, Bhathal P, Cornell H, Tomnley RRW. Gluten enteropathy in vitro: a culture system for the study of coeliac disease. Gut 1972; 13: 848.

41 Iyngkaran N, Yadav M, Balabaskaran S, Sumithran E. In vitro diagnosis of cow's milk protein sensitive enteropathy by organ culture method. Gut 1980; 22: 199-202.

42 Berteloot A, Chabot JG, Hugon JS. Turnover of mouse intestinal brush border membrane proteins and enzymes in organ culture. A direct evaluation from studies on the evolution of enzyme activities during the culture. Biochim Biophys Acta 1981; 678: 423-36.

43 Black BL, Yoneyama Y, Moog F. Microvillous membrane vesicle accumulation in media during culture of intestine of chick embryo. Biochim Biophys Acta 1980; 601: $343-8$.

44 Dougherty WJ. Microblebs of intestinal epithelial cell microvilli of Citellus tridecemlineatus. Anat Rec 1976; 185: $77-83$.

45 Trams EG, Lauter CJ, Salem N, Heine U. Exfoliation of membrane ecto-enzymes in the form of microvesicles. Biochim Biophys Acta 1981; 645: 63-70.

46 DeBroe ME, Wieme RJ, Logghe GN, Roels F. Spontaneous shedding of plasma membrane fragments by human cell in vivo and in vitro. Clin Chim Acta 1977; 81: $237-45$.

47 Trier JS. Organ culture of the mucosa of human small intestine. In: Curtis HC, Trump BF, Shoner GD, eds. Methods in cell biology. Normal human tissue and cell culture. New York: Academic Press, 1980: 365-83. 